\title{
HOHFELD ON PRIVILEGES AND LIBERTIES ${ }^{1}$
}

\author{
Daniel Simão Nascimento (UFRJ) ${ }^{2}$ \\ danielsimaonascimento@gmail.com
}

\begin{abstract}
Wesley Newcomb Hohfeld was an American jurist who published a series of articles between 1909 and 1917 that were very important for 20 th century analytical philosophy of right. In these articles, Hohfeld analyzed how jurists and judges alike use the word 'right' to speak of the rights of groups and individuals. Since he presented his articles, it has been commonplace among 'hohfeldian specialists' to distinguish rights into four groups: privileges, or claims, powers and immunities. This paper has four sections. In section I, I present Hohfeld's notion of privilege and point to a difficulty that has long been known by specialists, namely, that there are actually two significantly different legal relations that this notion is supposed to cover. In section II, I analyze and criticize the way (Wenar 2005) proposes we should define these two legal relations. In section III, I do the same with suggestion proposed by (Moritz 1960, 1073). In section IV, I present my own suggestion about how we should understand them.
\end{abstract}

Keywords: Hohfeld; Privilege; Liberty; Rights.

I.

Wesley Newcomb Hohfeld was an American jurist who published a series of articles between 1909 and 1917 that were very important for $20^{\text {th }}$ century analytical philosophy of right and established Hohfeld as a major precursor to the

\footnotetext{
${ }^{1}$ Recebido: 25-08-2017/ Aceito: 30-10-2017/ Publicado: 15-08-2019.

${ }^{2}$ Daniel Simão Nascimento é Professor adjunto na Universidade Federal do Rio de Janeiro, Rio de Janeiro, RJ, Brasil.
} 
deontic logic that was later formulated by Von Wright ${ }^{3}$. His two major contributions were the articles "Some Fundamental Legal Conceptions as Applied in Judicial Reasoning" (Hohfeld, 1913) and "Fundamental Legal Conceptions as Applied in Judicial Reasoning" (Hohfeld, 1917). In these articles, he analyzed how jurists and judges alike use the word 'right' to speak of the rights of groups and individuals such as the right of free speech, the right to vote, the right to abort and etc.

According to Hohfeld, although the word 'right' is used in juridical contexts to name several different juridical relations, there are some basic meanings of the word, each of those basic meanings express a clear and simple juridical fact and all rights are in fact complex juridical facts made up of the agglutination of these simple juridical facts. In his articles, Hohfeld distinguished between four forms of ascription of rights: ascriptions of 'privilege', 'right', 'power' and 'immunity'. Today, many hohfeldian specialists prefer to speak of 'liberty' instead of 'privilege' and of 'claim' instead of 'right'. Indeed, Hohfeld himself suggested the word 'claim' as a possible synonym of 'right' (Hohfeld 1913, 32), and he also held both that what we usually call legal liberties are legal privileges (Hohfeld 1913, 36), and that the closest synonym of legal privilege seems to be legal liberty (Hohfeld 1913, 41). In what follows, I have chosen to use 'claim' instead of right, 'privilege' instead of liberty and to quote authors in their own terms in order to respect their own choices.

The first mention of privileges in (Hohfeld 1913) comes when the author is discussing what he calls "operative facts". According to Hohfeld's nomenclature, operative

3 On this point see Saunders 1990: 465. 
facts are facts which, under the general legal rules, suffice to change legal relations so as to create a new relation, extinguish an old one, or perform both of these functions simultaneously (Hohfeld 1913, 25). The mention of privilege appears with the following examples of operative facts,

[...] if X commits an assault on $\mathrm{Y}$ by putting the latter in fear of bodily harm, this particular group of facts immediately create in $Y$ the privilege of self-defense - that is, the privilege of using sufficient force to repel X's attack; or, correlatively, the otherwise existing duty of $\mathrm{Y}$ to refrain from the application of force to the person of $\mathrm{X}$ is, by virtue of the special operative facts, immediately terminated or extinguished. (Hohfeld 1913, 26).

We find a second and most important passage about privileges a few pages ahead, when Hohfeld outlines his general conception of privilege. According to what is said there,

[...] if $X$ has a right against $Y$ that he shall stay off the former's land, the correlative (and equivalent) is that $\mathrm{Y}$ is under a duty toward $\mathrm{X}$ to stay off the place. If, as seems desirable, we should seek a synonym for the term "right" in this limited and proper meaning, perhaps the word "claim" would prove the best. [...] a privilege is the opposite of a duty, and the correlative of a "no-right". In the example last put, whereas $\mathrm{X}$ has a right or claim that $\mathrm{Y}$, the other man, should stay off the land, he himself has the privilege of entering on the land; or, in equivalent words, $\mathrm{X}$ does not have a duty to stay off. The privilege of entering is the negation of a duty to stay off. (Hohfeld 1913, 32).

In this passage Hohfeld uses the word 'right' to refer both to claims and privileges. Although his notion of claim is not the focus of this paper, it will be useful to have a working definition of it because it will inevitably appear in our argument. For our present purposes, we can say that accord- 
ing to Hohfeld an individual A has a legal claim against another when this other has a legal duty to to do something ${ }^{4}$. As for the notion of privilege, Hohfeld clearly identifies the legal privilege of entering with the negation of a legal duty to stay off. As many have noted, according to hohfeld a legal privilege is the 'jural opposite' of a legal duty, i.e. of a legal obligation, which means that the sentences 'a legal privilege to phi' and 'the absence of a legal duty not to phi' express one and the same legal fact ${ }^{5}$.

Although many specialists still adopt Hohfeld's formulations of the four incidents, some hold we have good reason to distinguish between two kinds of 'privilege'. In a way, I think it could be said that Hohfeld himself began pointing towards this fact already in 1913. For as soon as identified the privilege of entering with the negation of a duty to stay off, Hohfeld quickly added the following observation,

[...] when it is said that a given privilege is the mere negation of a

\begin{abstract}
${ }^{4}$ I take this to be a standard definition of the hohfeldian claim. See f. ex.: "this statement we are not asserting that the person having the privilege has an affirmative claim against another, i. e., that that other is under a duty to refrain from (...)" (Cook 1919, 725); “(...) I may very well be said to have a right to eat my dinner, because everybody else is under a duty to refrain from interference with my eating my dinner (Husik 1924, 266); "One party $\mathrm{x}$ has a legal claim against some second party that y do some action A if and only ify has a legal duty to $\mathrm{x}$ to do A" (Wellman 1997, 76); "the owner of a car has a claim against others that they not drive the car and others have a duty to the owner not to drive the car" (Rainbolt 2006, 1); "“A has a claim that B $\varphi$ [or not- $\varphi$ ] if and only if B has a duty to A to $\varphi$ [or not- $\varphi$ ]" (Wenar 2015, 5).

${ }^{5}$ F. ex. "“Privilege" therefore denotes absence of duty" (Cook 1919, 725); "a privilege is the correlative of a no-right and the negative of a duty" (Husik 1924, 266); "Privilege-right, therefore, is paraphrased by absence of duty" (Radin 1938, 1149); "a no-right and the corresponding privilege are converses of each other" (Fitch 1967, 269); "privilege $=$ df. no duty-not (no prohibition)" (Mullock 1970, 267); "X has a privilege against Y with regard to act A if and only if $Y$ has a noright against X with regard to A"; "x has a privilege against $\mathrm{y}$ to do $\mathrm{p}$ if and only if $\mathrm{x}$ has no duty to y not to do p" (Adams 1985, 85); "an individual has a privilege against a second individual with regard to a particular act if and only if the individual does not have a duty toward the second individual with regard to that act" (Saunders 1990, 468); "one party $\mathrm{x}$ has a legal liberty in face of some second party y to perform some action $\mathrm{A}$ if and only if $\mathrm{x}$ has no legal duty to $\mathrm{y}$ to refrain from doing A" (Wellman 1997, 76); "Liberties and no-claims are correlatives. X has a liberty against $\mathrm{Y}$ that $\mathrm{X}$ do $\mathrm{A}$ if and only if $\mathrm{Y}$ has a no-claim on $\mathrm{X}$ that $\mathrm{X}$ do $\mathrm{A}$ (Rainbolt 2006, 1-2); "A has a privilege to $\varphi$ if and only if A has no duty not to $\varphi$ " (Wenar 2015, 4-5).
\end{abstract}


duty, what is meant, of course, is a duty having a content or tenor precisely opposite to that of the privilege in question. Thus, if, for some special reason, $\mathrm{X}$ has contracted with $\mathrm{Y}$ to go on the former's own land, it is obvious that $\mathrm{X}$ has, as regards $\mathrm{Y}$, both the privilege of entering and the duty of entering. The privilege is perfectly consistent with this sort of duty,-for the latter is of the same content or tenor as the privilege; - but it still holds good that, as regards Y, X's privilege of entering is the precise negation of a duty to stay off. Similarly, if A has not contracted with B to perform certain work for the latter, A's privilege of not doing so is the very negation of a duty of doing so. Here again the duty contrasted is of a content or tenor exactly opposite to that of the privilege. (Hohfeld 1913, 32-33).

According to Hohfeld, then, if $X$ has made a contracted with $\mathrm{Y}$ that stated that $\mathrm{X}$ had to go to $\mathrm{Y}$ 's land in order to fix Y's roof, then we should say that X has both the privilege of entering Y's land and the duty of entering Y's land in order to fix Y's roof. But what if Y just invited X to come to his land at any given time at his own convenience? It seems that in this case $\mathrm{X}$ would not have either the duty to enter or the duty not to enter Y's land. This suggests the existence of two possible forms of this privilege: the privilege of going that comes with the duty of entering, and the privilege of going that comes with no such duty. The existence of this difference is of importance for our understanding of what kind of legal relations the concept of privilege is supposed to cover.

As we have already noticed, Hohfeld took privilege and liberty as close synonyms, and he thought that our legal liberties were legal privileges. Since we do not conceive of some of our our paradigmatic political and legal liberties, such as the liberty of religion, of freedom of expression and etc., as the kind of liberty that Hohfeld attributes to the contractor, who must enter someone's land in order to fulfill his contracted duty, but as a kind of liberty that comes 
without any legal duty to exercise it, it would be desirable to make room for this difference in the hohfeldian apparatus. In sections II and III, I consider and criticize the two attempts to do this that are available to us. In section IV, I suggest a new approach.

\section{II.}

As far as I can tell, the most recent attempt to differentiate between two kinds of privilege, namely, the one that was made in 2005, when prof. Leif Wenar presented his 'expanded hohfeldian model'.

According to Wenar's expanded model, we should make the following distinction between privileges,

A sheriff in hot pursuit of a suspect has the legal right to break down the door that the suspect has locked behind him. The sheriff's having a legal right to break down the door implies that he has no legal duty not to break down the door. [...] The sheriff's right is a single privilege. A right that is a single privilege confers an exemption from a general duty. (Wenar 2005, 225-226).

A paired privilege is composed of two privileges. The holder of a paired privilege has a privilege [no duty not] to phi, and also has a privilege [no duty not] not to phi. [...] A person vested with a paired privilege is entitled to perform some action, or not to perform that action, as he pleases. (Wenar 2005, 226-227).

Wenar's talk of exemption is of primary importance here. It is evident that any rights that confer exemptions of the kind supposed by Wenar would be classified as privileges according to Hohfeld, and that such rights do exist. Clear examples of rights that confer exemptions from general du- 
ties are certain rights conferred to people above a certain age, like the right not to pay for public transportation.

Nevertheless, Wenar's suggestion brings a considerable problem, namely, that it is hard to see why rights like these cannot be said to be paired privileges. According to Wenar's own definition, someone has a paired privilege if he has a privilege [no duty not] to phi, and a privilege [no duty not] not to phi. Why should we not say that elderly people who are exempt from the duty of paying for public transportation cannot be said to have a privilege not to pay for it and a privilege to pay for it? After all, it seems clear that in their case both actions become not only permitted but optional.

Although one could hope to appeal to Wenar's own examples for some further clarification of the difference he is proposing, they turn out to be of no help at all. According to him,

While ordinary citizens have a duty not to break down doors, police officers have a privilege-right [no duty not] to break down doors. When President Nixon asserted that he had a legal right not to turn over the Watergate tapes, he was asserting "executive privilege." Ordinary citizens have a legal duty to turn over evidence when subpoenaed. Yet Nixon alleged that because he was President he had a legal right [no duty not] not to turn over his evidence. James Bond's license to kill is also an exemption from a general duty. Bond's (alleged) right exempts him from a duty not to do what civilians emphatically have a duty not to do, viz., to kill. Similarly, your driver's license gives you the right to drive. This right exempts you from a duty not to do what you would otherwise have a strong duty not to do-to operate dangerous machinery at high speeds. (Wenar, 2005, p. 226).

As we can see, Wenar thinks we should class a police officer's right to break down doors, Nixon's right not to turn 
over the Watergate tapes, James Bond's license to kill and our right to drive as privileges that confer exemption and, therefore, as single privileges. But although in these cases the possession of a privilege does exempt the privilege holder of some duty, this exemption does not imply any sort of positive duty to do anything. Nixon could have turned over the Watergate tapes, and although I can't claim to know how exactly James Bond's license to kill works it seems clear that having a driver's license does not mean one has a duty to drive at any point. Therefore, it seems that in at least some of these cases the exemption in questions makes the action optional, and if the action is optional it is because there is not duty either to do it or not to do it.

I conclude that Wenar's definitions are importantly flawed. The author introduced two concepts which were supposed to divide privileges into two kinds, but they are unable to do so satisfactorily.

\section{III.}

The other attempt to make room for the difference between privileges in the hohfeldian apparatus was made by Moritz in $\$ 18$ of his book titled Uber Hohfelds System der juridischen Grundbegriff (1960) ${ }^{6}$. Moritz's thesis was then criticized in (Mullock 1970), and these criticisms were answereed in (Moritz 1973). In this latter article, Moritz defends his division of the notion of privilege into two different notions, Priv $_{1}$ and Priv2.

According to Moritz: "Privil (A) then means the same as

\footnotetext{
${ }^{6}$ Although it had long been remarked that Hohfeld's notion of privilege needed clarification see, for example, (Radin 1938, 1149), it seems that it was not until Moritz's book that interpreters concerned themselves seriously with separating the two kinds of relations we are discussing here.
} 
"PA", $\operatorname{Priv}_{2}(\mathrm{~A})$ means the same as "PA \& P-A". $\left(\operatorname{Priv}_{2} \mathrm{~A}\right)=$ (Priv 1 A) \& $\operatorname{Priv}_{1}(-\mathrm{A})$ " (Moritz 1973, 428). As the author himself clarifies, in this definition "PA" means "notforbidden", i.e. no duty not-to, a notion that is weaker than (PA \& P-A), i.e no duty to and no duty not-to, which the author takes to express 'indifference' in relation to an action. In this article, however, I prefer to use the term 'optional' instead of 'indifferent' to characterize actions of the second type.

Having said that, we can see that Moritz's suggestion is a simple one: there are two types of privilege, but the second type is formed by the agglutination of two privileges of the first type. Such result could seem welcome to hohfeldian scholars, for it would allow us to say that Hohfeld in fact isolated the basic form of the privilege, and that all other forms were merely derivative forms of privilege, composed by the agglutination of two privileges. Although this may seem to be an elegant and simple solution, it raises a puzzle that, as far as I can tell, has not yet been remarked.

The puzzle concerns the sense in which it could be said that a Priv 2 is the agglutination of two Priv 1 s of the kind proposed by Moritz in his formula. According to Moritz, an individual has a Priv 1 to phi if he has no duty not to phi, and an individual has a Priv 2 to phi if he has no duty not to phi and no duty to phi. Now, if we ask what is status of the individual who has a Priv 1 to phi as regards his phi-ing, it seems we must say he has no duty not to phi and a duty to phi. For it is plain that one either has or does not have a duty to phi, and that if he does not have this duty than he has a Priv 2 to phi, and not a Priv 1 . Having established that, let's ask how Moritz's suggestion would allow us to explain the formation of a Priv 2 to phi from the agglutination of a Priv 1 to phi and a Priv 1 not to phi. 
If what is said above is correct, we should say that a Privito phi is consists $\left(a_{1}\right)$ no duty not to phi and $\left(b_{1}\right)$ a duty to phi, and that a Priv 1 not to phi consists in $\left(\mathrm{a}_{2}\right)$ no duty to phi, and $\left(b_{2}\right)$ a duty not to phi. Now, if we add this two privileges it seems that what we get is a privilege that is twice contradictory, for it would be composed of $\left(a_{1}\right)$ no duty not to phi, $\left(b_{2}\right)$ a duty not to phi, $\left(b_{1}\right)$ a duty to phi and $\left(a_{2}\right)$ no duty to phi. How exactly are we supposed to 'add' all this up in order to get to what a Priv 2 is supposed to look like?

As far as I can see, the most we can say is that in a Priv 1 we find only one exemption from a duty while in a Priv 2 we find two exemptions from two duties, that each exemption, if given separately, can be an operative fact that creates a Priv $_{1}$, and that if both exemptions are granted to the same individual he will end up with a Priv2. But that is not enough for us to say that a Priv 2 is composed of the agglutination of two Privi's. Because of this, it seems to me that the best thing to do is to recognize that we are in fact in front of two legal relations that are basic. The reason Moritz could not see this is because he actually gave us an incomplete definition of $\operatorname{Priv}_{1}$ - his definition mentioned the exemption, but failed to mention the duty that must come with it when the privilege a Priv 1 and not a $\operatorname{Priv}_{2}$.

\section{IV.}

To conclude, we can redefine the two forms of privilege isolated by Moritz in the following manner: a Priv ${ }_{1}$ to phi is

\footnotetext{
${ }^{7}$ This is a point of Moritz's exposition which went unnoticed and unquestioned in Mullock's "Saving the hohfeldian privilege" (1977). Indeed, in (Mullock 1977, 256) we can see that the author assumes both the incomplete definition of $\operatorname{Priv}_{1}$ and the summative account of $\operatorname{Priv}_{2}$ offered by Mortiz, and both the definition and the account remain unchallenged in the rest of the paper.
} 
consists (a) no duty to phi and (b) a duty to phi, and a Priv2 consists in (a) no duty to phi and (b) no duty not to phi. In the first case, phi-ing is permitted and obligatory, and in the second case it is permitted and optional. Besides, we can also say that a Priv 2 to phi is not composed of the agglutination of a Priv 1 to phi and a Priv 1 not to phi and, therefore, we have reason to believe that a Priv2 is a second and basic form of privilege. Last but not least, it is worth noticing that these two types of privilege are importantly different.

Single privileges imply duties, and in non-contradictory legal systems a single simple privilege to phi must be attached to every duty to phi. Indeed, for a legal system to be noncontradictory one and the same individual cannot have at the same time a duty to phi and not to phi, i.e. be prohibited to phi and not to phi. Therefore, for a legal system to be non-contradictory it must be true that whenever one has a duty to phi one also has a duty not to phi and, therefore, one has a single privilege to phi. Legal Single privileges confer permission to act in accordance with duties so that the imposition of these duties generates no contradiction inside a legal system.

Paired privileges, on the other hand, are characterized by a double the absence of duty. When a legal system attributes a paired privilege to an individual, it is not conferring him permission not to act in accordance with a given duty. It is conferring permission to determine himself whether to act or not to act in a given way. These are the privileges which we associate with our dearest civil liberties.

If what is said above is correct, this difference is indeed too big for any summative account to overcome. 


\section{REFERÊNCIAS}

ADAMS, D. M. Hohfeld on Rights and Privileges. Archiv Für Rechts Und Sozialphilosophie,Stuttgart, v. 71,n. 1, p. 84-95, 1985.

FEINBERG, J. The Nature and Value of Rights. The Journal of Value Inquiry, Wisconsin, v. 4, n. 4, p. 243257, 1970.

HART, H. L. A. Are There Any Natural Rights? Philosohical Review, Durham, v. 64, n. 2, p. 175-191, 1955.

HOHFELD, W. N. Some Fundamental Legal Conceptions as Applied in Judicial Reasoning.. The Yale Law Journal, New Haven, v. 23, n. 1, p. 16, 1913.

. 1917. Fundamental Legal Conceptions as Applied in Judicial Reasoning." The Yale Law Journal, New Haven, v. 26, n. 8, p. 710, 1917.

HUSIK, I. Hohfeld's Jurisprudence. University of Pennsylvania Law Review and American Law Register, Philadelphia, v. 72, n. 3, p. 263-277, 1924.

MORITZ, M. Über Hohfelds System Der Juridischen Grundbegriffe. Lund: CWK Gleerub, 1960.

. On the Hohfeldian Privilege: Reply to Philip Mullock. Archiv Für Rechts Und Sozialphilosophie, Stuttgart, v. 59, n. 3, p. 427-432, 1973.

MULLOCK, P. "Manfred Moritz on the Hohfeldian Privilege." Archiv Für Rechts Und Sozialphilosophie, Stuttgart v. 56, n. 4, 545-548, 1970a. 
.The Hohfeldian No-Right: A Logical Analysis.Archiv Für Rechts Und Sozialphilosophie, Stuttgart, v. 56, n. 2, p. 265-272, 1970 b.

. Saving' the Hohfeldian Privilege. Archiv Für Rechts Und Sozialphilosophie, Stuattgart, v.63, n. 2, p. 255-259, 1977.

RADIN, M. A Restatement of Hohfeld. Harvard Law Review, Cambridge, v. 51, n. 7, p. 1141-1164, 1938.

RAINBOLT, G. The Concept of Rights. Dordrecht: Springer, 2006.

SAUNDERS, K. W. A Formal Analysis of Hohfeldian Relations. Akron Law Review, East Lansing, v. 23, n. 3, p. 465-506, 1990.

WELLMAN, C. An Approach to Rights: Studies in the Philosophy of Law and Morals. Dordrecht: Kluwer Academic Publishers, 1997.

WENAR, L. The Nature of Rights. Philosophy \& Public Affairs, New Jersey, v. 33, n. 3, p. 223-253, 2005.

. Rights. The Stanford Encyclopedia of Philosophy, $2015 . \quad$ Disponível em: http://plato.stanford.edu/archives/fall2015/entries/rights/.

Yates, A. A Hohfeldian Analysis of Hobbesian Rights. Law and Philosophy, Heidelberg, v. 32, n. 4, p. 405-434, 2013. 